\title{
Cultural Symbolism in an Italo-Australian Religious Festa
}

\author{
Stephen Torre \& Nerina Caltabiano
}

James Cook University-Cairns

\begin{abstract}
A religious festival of Sicilian origin is celebrated each year by the community of Silkwood in the tropical far north of Australia. The following account is based on the 50th anniversary of the foundation of the festival, held in 2000.
\end{abstract}

Between 230 and 233 AD three Spanish noblemen were born in Prefetta in Gascony. They practised their Catholic faith in peace under the reign of the Roman Emperor Alexander Severus, but his successor, Decius, began a cruel campaign against Christianity. Their mother, Benedetta, was martyred in her home town; her husband, Vitale, with their three sons and other Christians were marched to Rome, where Vitale was also tortured and killed. Because of their youth the brothers were forced further on to Sicily where Tertuillian hoped to persuade them to recant their Christian beliefs. Despite the prolonged tortures they suffered during their journey the brothers succeeded in converting twenty of their guards to the Christian faith. Infuriated at their unshakeable belief, their captors martyred the three brothers at Lentini on the $10^{\text {th }}$ May 253 AD: Alfio's tongue was torn out as punishment for praising Jesus Christ, and he bled to death; Filadelfo was bound to a grate and roasted over open flames; and Cirino, the youngest at 20 years of age, died after being plunged into a cauldron of boiling tar. Their remains were buried a short distance from Lentini, at a place now named St Alfio in memory of the three martyred brothers.

Some 1696 years later on the other side of the world in Australia, Rosario Tornabene, an immigrant from St Alfio, watches his wife Alfia become increasingly distressed during childbirth. He prays to Saint Alfio, Saint Filadelfo and Saint Cirino, his patron saints, to ask God to spare the lives of his wife and child, promising, if they survive, to bring relics and statues of the saints from Sicily. His prayers are answered and thenceforth each year on the first Sunday of May the Feast of the Three Saints is held in Silkwood, a township hidden away amongst the verdant canefields and tropical rainforests of Far North Queensland. 


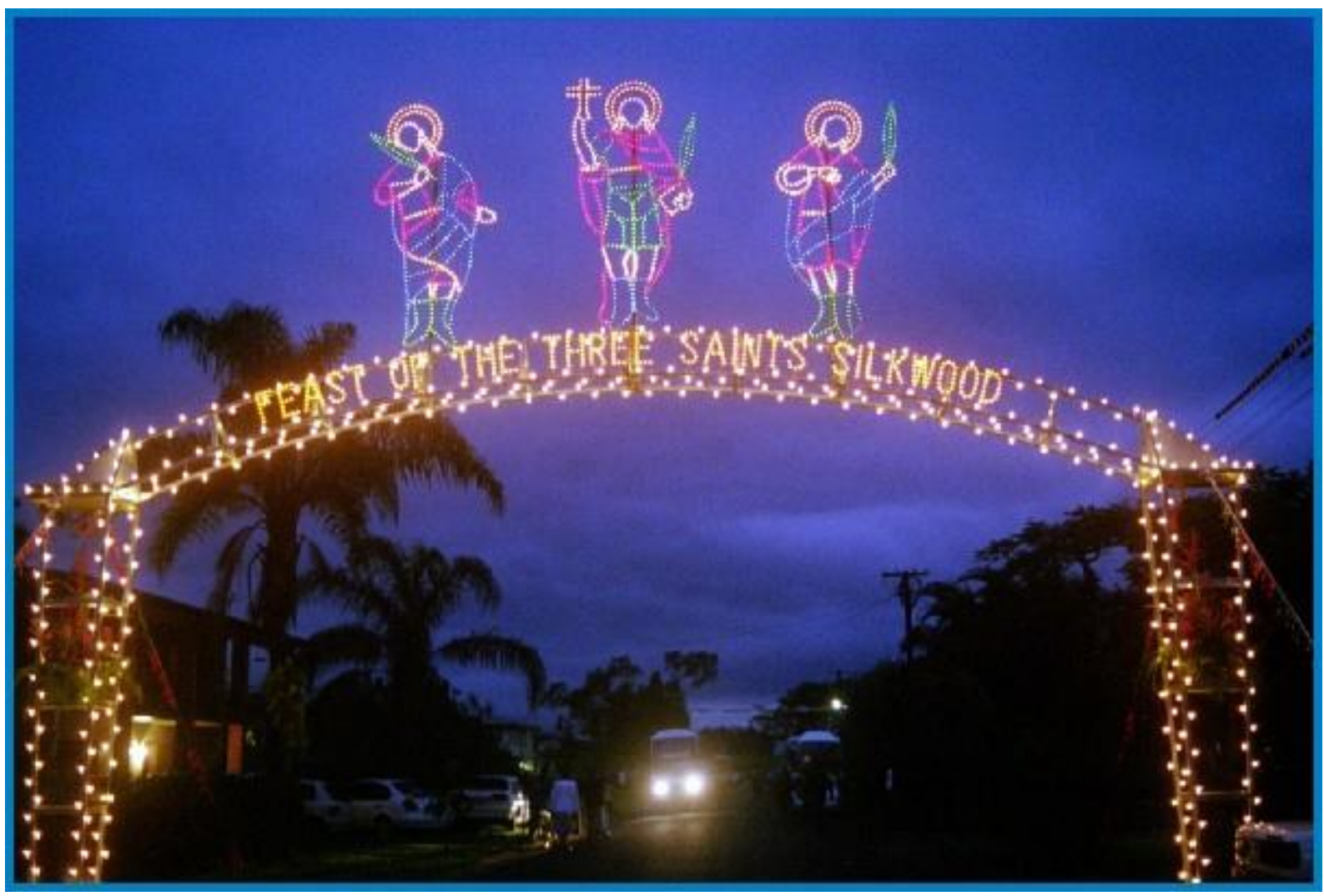

Today, in the year 2000, the fiftieth anniversary of the Feast is getting off to a wet start. Swollen grey clouds hang heavily and closely above, as preparations for a High mass begin. Above the altar a panel has been removed revealing, for this one day, the cappella (a chamber above the altar) in which stand the three statues brought from Sicily by Rosario Tornabene. At 10am the holy procession penetrates the crowd of thousands and enters the tiny church of St John the Evangelist. The mass is concelebrated in the tridentine Latin rite (with some Italian hymns intruding) by the Apostolic Nuncio, Rev. Francesco Canalini; the Bishop of Cairns, Bishop James Foley; Parish priest, Father Tom Mullins; and a Scalibrinian priest, Fr Mauro Conti. In the congregation are official guests: the Italian Ambassador to Australia, Dr Giovanni Castellaneta; the Italian Consul of Brisbane, Dr Antonio Alessandro; the Mayor of St Alfio, Dr Leonardo Patti; an executive of the Municipal Council of St Alfio, Mr Salvo Belfiore; assorted state and federal politicians; and representatives from religious and community groups. Bishop James, a lecturer in philosophy and member of the council of the Australian Catholic University rises. Known to worry at the complexities and difficulties of faith and belief in his homilies for the Catholic congregation of postmodernist Cairns, today he is solemn and reverential in his reflections on the simple and steely faith of saints, speaking in a sonorous English which complements the lushly passionate melodies of the St Alfio Choir. After the Eucharist is distributed to communicants 
and the blessings of powerful prelates bestowed on the faithful, the crowd surges out to the festivities.

This is reputedly the largest religious festival held in Australia and organizers are expecting 7000 on this fiftieth anniversary. An area half the size of a soccer stadium is covered with marquees under which long trestle tables and bench seats from the nearby school are arranged as for a banquet. At one end on a stage "Domenico "welcomes everyone in Italian, draws out his accordion to its widest span, and taking a deep breath himself launches into traditional Italian songs, and later, as the day wears on, modern San Remo repertoire. The theme colours for the festival are green and red, the colours traditionally associated with the three saints. These are repeated everywhere, in the fabric of the marquees and in decorative flags, in the dress of matrons and their daughters, in the flowers and adornments of the altar. Two huge air socks, one green, one red, flick 20 metres into the air as they breathe in the sharp exhalations of electric wind generators. Even some of the food carries through the colour theme: the most popular of the many food stalls for which the queue stretches 100 strong all day long serves a bread roll filled with fennel-flavoured pork sausage, red and green capsicums and eggplant with pitch black skin, all of which are grilled over flames as a reminder of the sufferings endured by the Saints. Most of the food takes on this eucharistic dimension through its association with suffering and salvation. There are lupini and roasted chickpeas, nutritious and portable for those undertaking a long journey by foot. Ossi di morti, small bone-like pieces of toffee flavoured with cinnamon and ossified in the baking through the addition of flour, presage Death and evoke the earthly remains of the three martyrs. In the last days before their arrival at Lentini, the ill-fated brothers sustained themselves on chestnuts. At what was later named Trecastagni, the discarded shells of roasted chestnuts consumed by the saints miraculously germinated and formed three trees which grew together as one, and remain to this day an emblem of the possibility of new life springing from the darkest of despair. Today everyone is aware of this, who eats the faintly sweet and powdery flesh of coal-roasted castagni with burning blackened fingers.

But this is a festa; so there are hamburgers and chips and hot dogs and Fanta for the children, and even six packs of beer smuggled in in green and red coolers. For three hours people eat, drink and reminisce about the old days when there was no Feast day to lighten the backbreaking labour in the hot and wet fields of heavy red volcanic soil; about the loved ones who stayed behind to deal with the tyrannical padrone, the greedy mafiosi and the Fascist thugs; 
of how such and such a son or daughter is now a doctor in Brisbane, a restauranteur in Carlton, a lawyer in Sydney, an academic in Adelaide; of how Giovanni has three sons and two daughters and recently visited his relatives in Sicily or of how Venera still wears her gold chain with the medal of St Alfio even though she has spiked yellow hair and wears silver studded black leather; of how the saints have watched over the unfolding sadness and happiness of the lives in their extended families. Although it has not rained, from time to time a mist-like precipitation has hung low in the air preventing the escape of the sweet sour smoke of cooking and the din of passionate conversation, singing and laughter. Legend has it that rain will never spoil this day, and in fact with a slight lifting of the heavy atmosphere everyone now knows it is time for the most important event of the day.

The crowds flow back towards the church in which the three statues of the saints are silently gliding (through the agency of some invisible mechanism) forwards and down from their capella onto the vara, a gold plated contraption, more ornate than a haughty cardinal's sedan, in which they will be paraded through the town and fields of Silkwood. As the vara is wheeled forward out of the church by black-suited members of the festival committee the church bell begins to toll. Once in the open the vara pauses and the first of the fumogena bombe (smoke bombs) explode forcing infants to clap hands to ears. The faithful now press forward and make their offerings: though the saints are richly decorated with watches and jewellery of gold, precious gems, rosaries and other valuables, today it is mostly money which is handed up to the custodians who place the notes, sometimes thick rolls of 50s into the red velvet bags which hang at each corner of the vara. With each donation the custodians cry out in a full voice "Con buona fede, viva Sant'Alfio" (With true faith, long live Saint Alfio). Parents proffer infants wound in snow-white Christening silk; and these too are taken in both hands by a custodian who holds the infant aloft with arms fully stretched and cries out "Con buona fede, viva Sant'Alfio". A thousand red and green balloons are released: they rise rapidly into the air and float away together, breaking up and dispersing over distant canefields. In the next moment a crop-dusting plane sweeps terrifyingly low showering the vara and the crowd with red and green blossoms. Four men now grasp a wheelchair, occupant with lolling head and all, and amazingly hoist it up before the loving gazes of Alfio, Filadelfo and Cirino. With the chanting of the crowd, the tolling of the bell, the impact of the fumpogena bombe, the tears and joy, the vara begins to move slowly forward. 
Preceding the saints on their annual processione, a symbolic repetition of their original via dolorosa, are a young man carrying a crucifix, the committee officials, children dressed in the traditional costumes of their village or province and then the clergy. Following the vara are women dressed in green and red, some barefooted, and then everyone else. In the not too distant past in Sicily it was common for especially devout followers to make the journey shuffling on hands and knees, and some might even lick the ground over which the saints had passed, eventually leaving glistening streaks of blood and spittle from lacerated tongues. But today the recitation of the rosary and the singing of hymns suffices as atonement. The saints look wonderingly left, right and centre while the bells continue to ring and the smoke bombs to explode as the procession winds its way through Silkwood arriving back at the festival in time for the second of the day's masses, la messa festiva, which will be said in Italian by a priest of the Scalabrinian order, traditional pastors to the Sicilians. This mass is held in the school hall, the better to accommodate the greater numbers, though despite this the crowds spill over onto verandahs and even into the open where they merge imperceptibly with the merrymakers. Between the religious ceremony inside with its Italian hymns and the festivities under the marquee where Domenico is singing "Volare", between the sacred and the secular, there is now no clear boundary.

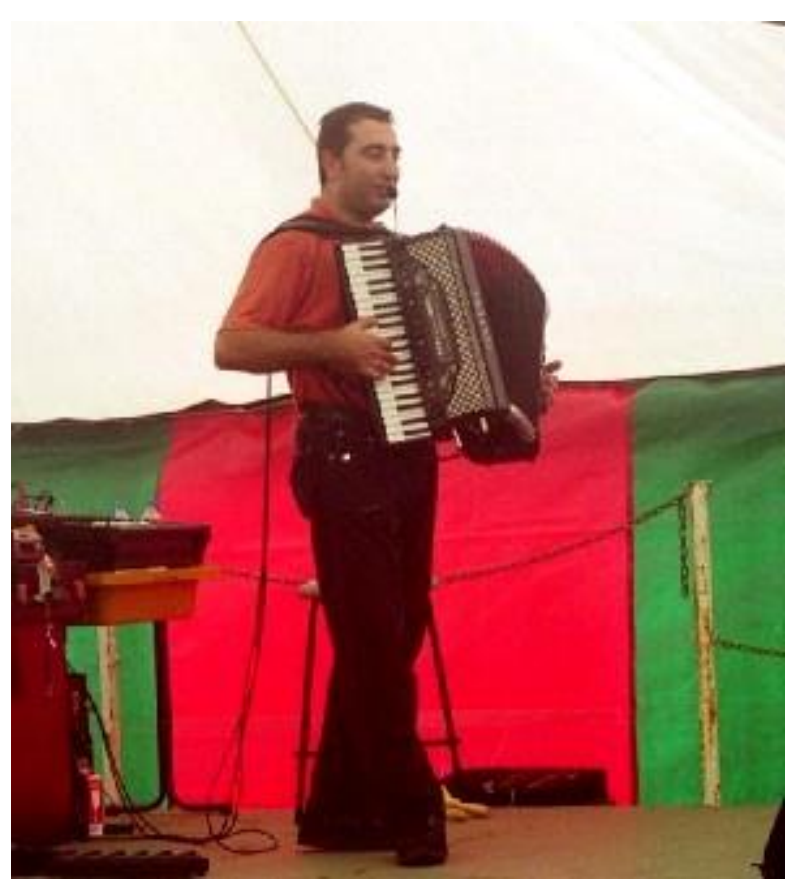

Meanwhile the saints stand in the open making themselves available for private adoration. One woman carefully pins her deceased husband's watch to the heart shaped shield worn by Saint Filadelfo. A man prostrates himself in turn before each idol and kisses the feet while 
praying that his wife will be miraculously cured of her cancer. Another woman blesses herself with the sign of the cross and before turning reluctantly away caresses the cheek of young Cirino. An elderly man with walking stick limps to the vara and puts his lips to a miniature monstrance. Through the lens of this reliquary one can see a dusty shadow, the remains of a piece of bone unearthed from the Sicilain graveyard of the three saints. It is unimaginable that the kisses, caresses, touches and gazes of these devotees fall on mere plaster and paint. The saints themselves have an uncannily life-like aura. Most religious statuary is slightly larger than life-size, but these idols are curiously non-standard, not much above a metre tall, perhaps to emphasize the youth of the three brothers. One feels drawn to them as to one's own children, while unsmiling, they seem to focus with wonder on something not visible to ordinary mortals. One can move back and forth in front of them, but the gaze has no identifiable focal point. If one could look through their eyes a rift might open in one's consciousness and a world where the ordinary and the religious are intermingled would be unconcealed, a world not unlike that of today's festival, where the generations gather in the presence of a heavenly and eternal family.

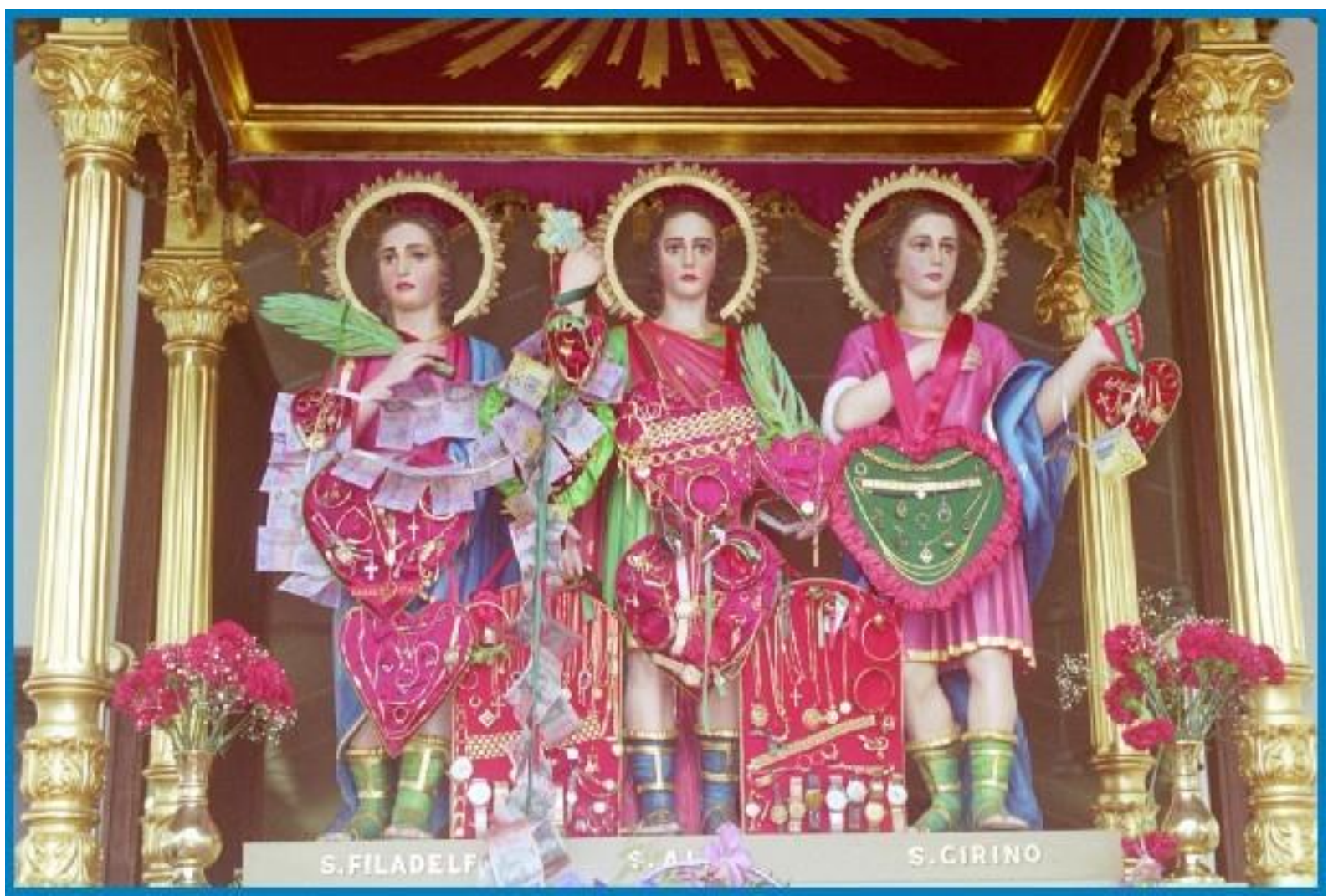

Dusk approaches and soon there will be dinner, then fireworks, and after, dancing and farewells. Late that night when the revellers have dispersed to their narrow beds, the 
custodians will place the idols back into their sealed capella, where they will remain hidden from human eyes for another year. A red velvet curtain conceals the chamber, and in front of this hangs a crucifix, suspended over the altar. At about midnight, the sleeping revellers will stir momentarily as the iron roofs of their houses rattle with the sudden onset of a monsoonal downpour which does not abate until the dawn of a grey Monday. 